\title{
Perbedaan Hasil Belajar Fisika Antara Model Pembelajaran Kooperatif Tipe Group Investigation dan Model Pembelajaran Kooperatif Tipe Think Pair Square pada Siswa Kelas X SMA Negeri 9 Palu
}

\author{
Pandi, Muhammad Ali, dan Sahrul Saehana \\ Pandiphysic11@gmail.com \\ Program Studi Pendidikan Fisika FKIP Universitas Tadulako \\ Jl. Soekarno Hatta Km. 9 Kampus Bumi Tadulako Tondo Palu - Sulawesi Tengah
}

\begin{abstract}
Penelitian ini dilakukan dengan tujuan mengetahui perbedaan hasil belajar fisika antara model pembelajaran kooperatif tipe group investigation dan model pembelajaran kooperatif tipe think pair square pada siswa kelas x SMA Negeri 9 Palu. Jenis penelitian ini merupakan eksperimen kuasi dengan desain equivalent pretestposttest. Populasi penelitian adalah siswa kelas X SMA Negeri 9 Palu. Tekhnik pengambilan sampel yang digunakan dalam penelitian ini adalah purposive sampling dengan sampel penelitian adalah kelas $X$ B sebagai kelompok eksperimen 1 dan kelas X C sebagai kelompok eksperimen. Instrumen hasil belajar fisika berupa tes piihan ganda. Tes hasil belajar fisika yang diperoleh menunjukkan bahwa skor rata-rata kelompok eksperimen 1 yaitu 12,29 lebih tinggi dari kelas eksperimen 2 yaitu 10,46. Uji hipotesis uji $\mathrm{t}$ (dua pihak), diperoleh $\mathrm{t}_{\text {hitung }}=$ 2,11 dan $t_{\text {tabel(0.975)(50) }}=2,02$ pada taraf nyata $a=0,05$. Ini berarti bahwa nilai $t_{\text {hitung berada di luar daerah }}$ penerimaan Ho. Dengan demikian dapat disimpulkan bahwa ada perbedaan hasil belajar fisika antara model pembelajaran kooperatif tipe group investigation dan model pembelajaran kooperatif tipe think pair. Tingginya hasil belajar fisika siswa kelas eksperimen 1, disebabkan karena kelas ekperimen 1 menggunakan model pembelajaran kooperatif tipe group investigation, sehingga siswa berperan aktif dalam proses pembelajaran dan secara kreatif menemukan permasalahan yang diajukan.
\end{abstract}

Kata Kunci : Model Pembelajaran Group Investigation, Think Pair Square, Hasil Belajar Fisika

\section{PENDAHULUAN}

Menurut kebanyakan orang bahwa belajar merupakan suatu kegiatan yang tidak menarik dan membosankan, sedangkan dengan belajar akan menambah pengetahuan terhadap sesuatu. Dengan belajar seseorang paham akan tujuan diciptakan dirinya, lingkungannya, dan mengetahui makna dirinya dan lingkungannya Ilmu Pengetahuan Alam (IPA) merupakan sebuah cara untuk mencari tahu tentang alam secara sistematis. Dengan demikian, IPA bukan hanya penguasaan kumpulan pengetahuan yang berupa fakta, konsep atau prinsip saja, tetapi juga merupakan suatu proses penemuan. Dalam proses pembelajaran IPA menekankan pada pemberian pengalaman langsung untuk mengembangkan kompetensi menjelajahi dan memahami alam sekitar secara ilmiah.

Pada umumnya pelajaran IPA adalah suatu pelajaran untuk mengetahui diri sendiri dan lingkungannya. Seharusnya pembelajaran fisika harus dikaitkan dalam kegiatan sehari-hari, sehingga konsep ilmu yang ada pada fisika dapat mereka terapkan dalam kehidupannya. Namun pada kenyataanya dalam kegiatan belajar mengajar siswa hanya mendengar informasi dari guru tanpa mengetahui apa konsep yang diberikan oleh guru tersebut. Sehingga hanya guru yang aktif di kelas dalam proses belajar mengajar dan siswa hanya diam, sedikit bertanya karena guru yang aktif. Oleh karena itu siswa kehilangan motivasi belajar, karena selalu guru yang memberi informasi dan siswa tidak dapat berkembang untuk membuka wawasan mereka sendiri. Hal ini menyebabkan siswa tidak dapat membuka wawasan mereka, dan untuk mengatasinya seorang guru harus lebih kreatif untuk dapat menerapkan model pembelajaran untuk siswa agar mereka dapat termotivasi untuk lebih aktif dikelas, mereka dapat berkembang dan dapat menghubungkan apa yang mereka pelajari dengan kehidupan seharihari.

Pembelajaran dengan menggunakan model Group Investigation berbasis eksperimen inkuiri terbimbing dapat memacu aktivitas dan motivasi siswa. Siswa dituntut aktif dalam pembelajaran dengan bekerjasama dalam kelompoknya untuk melakukan investigasi kelompok sebagai usaha dalam memecahkan masalah. Melalui kegiatan eksperimen inkuiri terbimbing siswa berperan langsung dalam pembelajaran dan berusaha 
p-ISSN 2338-3240, e-ISSN 2580-5924

menemukan konsep yang dituju, sehingga kemampuan berpikir siswa dapat berkembang ${ }^{[1]}$.

Model pembelajaran kooperatif tipe group investigation berbantuan laboratorium memudahkan siswa dalam perencanaan dan investigasi, laboratorium memberikan kesempatan siswa untuk bereksperimen, mengurai pengetahuan yang lebih kompleks dan mengambil kesimpulan dari pengamatan di laboratorium. Proses investigasi siswa dalam bereksperimen akan meningkatkan hasil belajar fisika siswa di sekolah[2]. Hal ini disebabkan siswa yang diajar dengan model pembelajaran Group Investigation dapat melatih siswa untuk dapat memadukan antara konsep yang mereka dapatkan dari penjelasan guru di kelas dengan konsep didapatkan dari buku- buku maupun internet. Dengan ini siswa diajarkan untuk dapat bekerja sama secara berkelompok dalam menyelesaikan berbagai masalah dan membuat alternatif untuk mengatasi permasalahan yang dihadirkan oleh guru mengenai materi yang dikaji, maka konsep-konsep yang telah dipelajari dan dikuasai siswa diharapkan dapat bermanfaat bagi dirinya dan dapat digunakan untuk menyelesaikan masalah yang dihadapinya di lingkungan sosialnya ${ }^{[3]}$.

Model pembelajaran kooperatif tipe Think Pair Square meningkatkan kemampuan berpikir siswa dalam mengeluarkan ide - ide untuk menyelesaikan masalah yang dihadapi baik itu pada soal tes pemahaman konsep maupun pada kehidupan nyata itu akan lebih baik ketika siswa diajarkan dengan model pembelajaran kooperatif tipe Think Pair Square dibandingkan dengan siswa yang diajarkan dengan model pembelajaran konvensional[4]. Model pembelajaran kooperatif tipe think pair square digunakan untuk meningkatkan kemampuan berpikir, berkomunikasi, dan mendorong siswa untuk berbagi informasi dengan siswa lain. Dalam pembelajaran kooperatif tipe think pair square membagi siswa kedalam Kelompok secara heterogen yang terdiri dari empat orang $^{[5]}$.

Berdasarkan uraian di atas, maka diasumsikan bahwa kedua pembelajaran ini dapat meningkatkan hasil belajar dan menjadikan pembelajaran berlangsung menyenangkan. Oleh karena itu, pada penelitian ini akan diterapkan model pembelajaran kooperatif tipe think pair square dan model pembelajaran kooperatif tipe group investigation, untuk meningkatkan hasil belajar dan mengubah persepsi siswa terhadap pelajaran fisika menjadi lebih positif. Pada penelitian ini akan diterapkan dua jenis model pembelajaran: yaitu model pembelajaran kooperatif tipe think pair square dan model pembelajaran kooperatif tipe group investigation. Kedua model pembelajaran ini dianggap akan dapat memberikan jawaban terhadap permasalahan sebagaimana diuraikan pada penjelasan di atas. Hal itu dikarenakan kedua model pembelajaran tersebut merupakan model pembelajaran yang lebih bermakna sehingga dapat membekali siswa dalam menghadapi permasalahan siswa khususnya fisika yang akan mereka hadapi dalam sekolah dan lingkungannya. Berdasarkan uraian di atas, peneliti bermaksud untuk melakukan penelitian yang bertujuan untuk melihat perbedaan hasil belajar fisika antara model pembelajaran kooperatif tipe group investigation dan model pembelajaran kooperatif tipe think pair square pada siswa kelas X SMA Negeri 9 Palu.

\section{METODE PENELITIAN}

Penelitian yang akan dilakukan adalah menggunakan metode kuasi dengan desain penelitian berupa "The equivalen pretest-posttest design" atau rancangan prates-pascates yang ekuivalen, yaitu memilih kelas-kelas yang diperkirakan sama kondisinya. Artinya tingkat kecerdasannya hampir sama, sehingga kelas yang satu dijadikan sebagai kelas eksperimen pertama dan kelas yang satunya lagi dijadikan sebagai kelas eksperimen kedua. Jenis desain penelitian ini dapat dilihat pada Tabel $1^{[6]}$.

Tabel 1

Desain Penelitian : The equivalen pretest-posttest

\begin{tabular}{|l|l|l|l|}
\hline Group & $\begin{array}{l}\text { Tes } \\
\text { Awal }\end{array}$ & Perlakuan & $\begin{array}{l}\text { Tes } \\
\text { Akhir }\end{array}$ \\
\hline $\begin{array}{l}\text { Kelas } \\
\text { Eksperimen ke- } \\
1\end{array}$ & $\mathrm{O}_{1}$ & $\mathrm{X}_{1}$ & $\mathrm{O}_{2}$ \\
\hline $\begin{array}{l}\text { Kelas } \\
\text { Eksperimen Ke- } \\
2\end{array}$ & $\mathrm{O}_{1}$ & $\mathrm{X}_{2}$ & $\mathrm{O}_{2}$ \\
\hline
\end{tabular}

Keterangan :

$\mathrm{X}_{1} \quad$ : Kelompok dengan Model Group Investigation

$\mathrm{X}_{2}$ : Kelompok dengan Model Think Pair Square

$\mathrm{O}_{1}:$ Tes awal (pretest)

$\mathrm{O}_{2}$ : Tes akhir (posttest)

populasi dari penelitian ini adalah seluruh siswa kelas $X$ di SMA Negeri 9 Palu tahun ajaran 2015-2016. Pengambilan sampel dilakukan dengan menggunakan teknik penentuan sampel dengan pertimbangan tertentu (Purposive Sampling $)^{[7]}$ yaitu dengan pertimbangan kemampuan siswa dengan cara mengetahui keadaan sebelumnya terhadap nilai hasil belajar siswa yang dimiliki guru sebagai bahan pertimbangan penentuan sampel yaitu memilih 
kelas yang hasil ujian rata - ratanya hampir sama yang dilakukan oleh guru mata pelajaran dan peneliti.

\section{HASIL dan PEMBAHASAN}

Hasil dari pemberian tes yang mengacu pada soal hasil belajar fisika yang diberikan pada kelas eksperimen 1 dan kelas eksprimen 2 disajikan pada Tabel 2

Tabel 2 Deskripsi skor tes hasil belajar fisika untuk kelas eksperimen 1 dan kelas eksprimen 2

\begin{tabular}{|l|c|c|c|c|}
\hline \multirow{2}{*}{ Uraian } & \multicolumn{2}{|c|}{ Pretest } & \multicolumn{2}{c|}{ Posttest } \\
\cline { 2 - 5 } & $\begin{array}{c}\text { Eksperi } \\
\text { men 1 }\end{array}$ & $\begin{array}{c}\text { Ekspri } \\
\text { men 2 }\end{array}$ & $\begin{array}{c}\text { Eksperi } \\
\text { men 1 }\end{array}$ & $\begin{array}{c}\text { Eksperi } \\
\text { men 2 }\end{array}$ \\
\hline Sampel (n) & 26 & 26 & 26 & 26 \\
\hline $\begin{array}{l}\text { Nilai } \\
\text { maksimum }\end{array}$ & 12 & 12 & 18 & 16 \\
\hline $\begin{array}{l}\text { Nilai } \\
\text { minimum }\end{array}$ & 2 & 2 & 7 & 6 \\
\hline $\begin{array}{l}\text { Skor rata- } \\
\text { rata }\end{array}$ & 6,77 & 6,00 & 12,29 & 10,46 \\
\hline $\begin{array}{l}\text { Standar } \\
\text { deviasi }\end{array}$ & 2,96 & 2,84 & 2,66 & 3,30 \\
\hline
\end{tabular}

Adapun persentase perolehan dari skor rata-rata hasil belajar fisika pada siswa baik tes awalnya maupun tes akhirnya dapat dilihat pada Gambar 1 dan 2

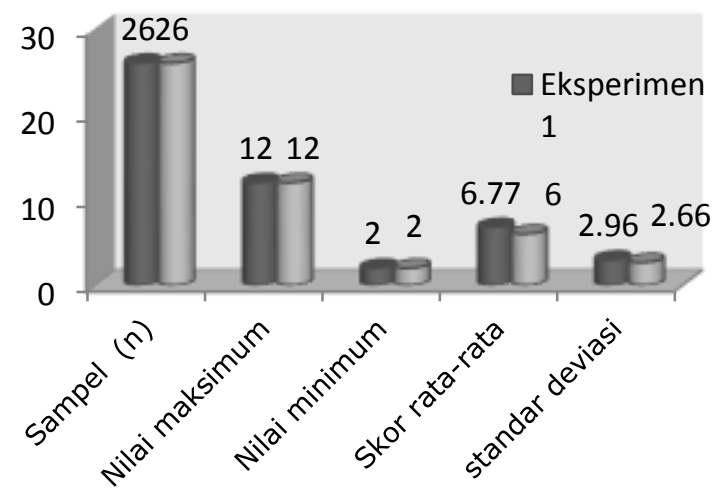

Gambar 1 : Sampel, Nilai Maksimum, Nilai Minimum, Skor rata-rata dan Standar Deviasi Tes Akhir (Pretest) Kelas Eksperimen 1 dan Kelas Eksperimen 2
p-ISSN 2338-3240, e-ISSN 2580-5924

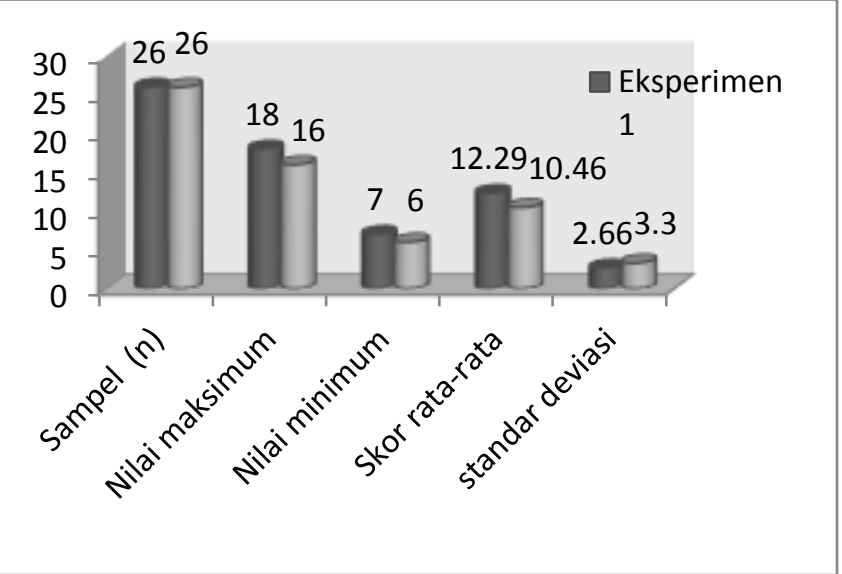

Gambar 2 : Sampel, Nilai Maksimum, Nilai Minimum, Skor rata-ratadan Standar Deviasi Tes Akhir (Posttest) Kelas Eksperimen 1 dan Kelas Eksperimen 2

Berdasarkan dua gambar di atas maka dapat dilihat terdapat perbedaan hasil belajar fisika dari kedua kelas tersebut yaitu antara kelas eksperimen 1 dan kelas eksperimen 2 . Sedangkan sebelumnya juga terdapat perbedaan yang sangat sedikit sehingga kedua kelas tersebut bisa dikatakan memiliki pemahaman awal yang sama mengenai materi tersebut.

Berdasarkan nilai rata-rata pretest kelas eksperimen 1 sebesar 6,77 dan kelas eksperimen 2 sebesar 6,00, dilakukan uji hipotesis (Uji-t) beda rata-rata (dua pihak) dan diketahui nilai thitung $=0,90$. Selanjutnya untuk nilai tabel dimana tabel $=t_{(1-1 / 2 a)}$ pada taraf nyata $a=0,05$ dan $d k=\left(n_{1}+n_{2}-2\right)=26+$ $26-2=50$, diperoleh $t_{0,975(50)}=2,02$. Data tersebut disajikan pada tabel 4.4 berikut.

Tabel 3 : Uji beda rata-rata (dua pihak) Pretest

\begin{tabular}{|l|l|l|l|l|l|}
\hline \multicolumn{6}{|c|}{ Kelas Eksperimen 1 dan Kelas Eksperimen 2} \\
\hline No & Kelas & $\begin{array}{l}\text { Nilai } \\
\text { rata- } \\
\text { rata } \bar{X}\end{array}$ & $\begin{array}{l}\mathrm{t} \\
\text { hitung }\end{array}$ & $\begin{array}{l}\mathrm{T}_{\text {tabel }} \\
(\mathrm{a}= \\
0.05)\end{array}$ & Keputusan \\
\hline 1 & $\begin{array}{l}\text { Kelas } \\
\text { Eksperime 1 }\end{array}$ & 6,77 & 0,90 & 2,02 & $\begin{array}{c}\mathrm{H}_{0} \\
\text { diterima }\end{array}$ \\
\hline 2 & $\begin{array}{l}\text { Kelas } \\
\text { Eksperime 2 }\end{array}$ & 6.00 & 0,90 & \\
\hline
\end{tabular}

Berdasarkan data Tabel 3 dan kriteria pengujian dimana $\mathrm{H}_{0}$ diterima jika $-\mathrm{t}_{(1-1 / 2 \mathrm{a})}<\mathrm{t}<$ $\mathrm{t}_{(1-1 / 2 \mathrm{a})}$, diketahui $-2,02<0,90<2,02$. Nilai thitung berada pada daerah penerimaan $\mathrm{H}_{\mathrm{o}}$. Dengan kata lain, bahwa tidak terdapat perbedaan hasil belajar fisika siswa antara kelas yang mendapatkan pembelajaran menggunakan model group investigation dengan kelas yang mendapatkan pembelajaaran menggunakan model think pair square. Tidak adanya perbedaan hasil pretest menunjukkan bahwa kedua kelas memiliki kemampuan awal yang sama, sehingga kedua kelas ini memenuh syarat untuk dijadikan sampel. 
Berdasarkan nilai rata-rata posttest kelas eksperimen 1 sebesar 1,29 dan kelas eksperimen 2 sebesar 10,46, dilakukan uji hipotesis (Uji-t) beda rata-rata (duapihak) dan diketahui nilai $t_{\text {hitung }}=2,11$. Selanjutnya untuk nilai tabel dimana tabel $=\mathrm{t}_{(1-1 / 2 \mathrm{a})}$ pada taraf nyata $\mathrm{a}=0,05$ dan $\mathrm{dk}=\left(\mathrm{n}_{1}+\mathrm{n}_{2}-2\right)=26+26-2=50$, diperoleh $t_{0,975(50)}=2,02$. Data tersebut disajikan pada Tabel 4.5 berikut.

\begin{tabular}{|c|c|c|c|c|c|}
\hline \multicolumn{5}{|c|}{$\begin{array}{c}\text { Tabel } 4 \text { : Uji beda rata-rata (dua pihak) } \\
\text { Kelas Eksperimen } 1 \text { dan Kelas } \\
\text { Eksperimen } 2\end{array}$} & Posttest \\
\hline No & Kelas & $\begin{array}{l}\text { Nilai } \\
\text { rata- } \\
\text { rata } \overline{\mathrm{X}}\end{array}$ & $\begin{array}{l}\mathrm{t} \\
\text { hitung }\end{array}$ & $\begin{array}{l}T_{\text {tabel }} \\
(a= \\
0.05)\end{array}$ & Keputusan \\
\hline 1 & $\begin{array}{l}\text { Kelas } \\
\text { Eksperime } 1\end{array}$ & 12,29 & & & \\
\hline 2 & $\begin{array}{l}\text { Kelas } \\
\text { Eksperime } 2\end{array}$ & 10,46 & 2,11 & 2,02 & diterima \\
\hline
\end{tabular}

Berdasarkan data Tabel 4.5 diketahui thitung $\geq t_{\text {tabel }}$ atau $2,11 \geq 2,02$. Hal ini berarti,nilai thitung berada di luar daerah penerimaan $\mathrm{H}_{0}$. Dengan demikian $\mathrm{H}_{0}$ ditolak dan $\mathrm{H}_{1}$ diterima, dan dapat disimpulkan bahwa terdapat perbedaan rata-rata hasil belajar fisika antara kelompok siswa yang mengikuti model pembelajaran kooperatif tipe group investigation dengan model pembelajaran kooperatif tipe think pair square. Dengan kata lain, nilai hasi belajar kelas eksperimen 1 lebih tinggi dibanding dengan kelas eksperimen 2 .

Tes dilakukan sebelum dan sesudah pembelajaran berlangsung. Setelah melakukan tes awal baik pada kelas eksperimen 1 maupun pada kelas eksperimen 2 maka pada masingmasing kelas memperoleh rerata skor yaitu pada kelas eksperimen $1(6,77)$ dan kelas eksperimen $2(6,00)$. Dari nilai yang diperoleh tersebut, kemudian dilakukan uji normalitas dan uji homogenitas yang dimaksudkan untuk melihat kondisi awal hasil belajar fisika dari kedua kelas tersebut. Hasil dari kedua uji tersebut menyatakan bahwa tidak ada perbedaan yang signifikan antara kelas eksperimen 1 dan kelas ksperimen 2. Hal ini dapat dilihat setelah dilakukan uji parametrik dua pihak yang menyatakan bahwa kedua kelas tersebut merupakan sampel yang berasal dari kelas yang homogen. Untuk itu dapat dikatakan bahwa kedua kelas memiliki kemampuan awal yang sama.

Untuk kemampuan akhir siswa dengan pemberian posttest diketahui skor rata-rata untuk kelas eksperimen 1 sebesar 12,96 dan untuk kelas eksperimen 2 sebesar 10,46. Hasil ini menunjukan adanya perbedaan skor antara kedua kelas, dimana skor rata-rata kelas eksperimen 1 lebih tinggi dibandingkan kelas eksperimen 2. Berbeda halnya dengan pretest,
p-ISSN 2338-3240, e-ISSN 2580-5924

hasil pemberian posttest ini didukung oleh hasil analisis uji hipotesis (Uji-t) dua pihak. Dimana dari perhitungan diperoleh nilai thitung $=2,11$ dan $t_{\text {tabel }}=2,02$. Berdasarkan hasil tersebut diketahui nilai thitung $\geq$ ttabel $_{\text {atau }} 2,11 \geq 2,02$, yang artinya hipotesis $\mathrm{H}_{1}$ diterima. Dengan kata lain terdapat perbedaan hasil belajar fisika antara kedua kelas baik yang menggunakan model pembelajaran kooperatif tipe group investigation maupun kelas yang menggunakan model pembelajaran kooperatif tipe think pair square.

Model pembelajaran group investigation memiliki tahapan pembelajaran yang dapat menekankan pada partisipasi siswa dan aktivitas siswa untuk mencari sendiri materi pelajaran yang akan dipelajari siswa. Melatih siswa untuk menumbuhkan kemampuan berfikir mandiri sehingga siswa terlibat secara aktif dalam pembelajaran dari tahap pertama hingga akhir. Hal ini disebabkan oleh penerapkan model pembelajaran group investigation siswa lebih antusias mengikuti pelajaran.

Pada tahap awal guru menghadirkan masalah yang sering mereka alami sehingga akan menimbulkan konflik kognitif pada siswa. Misalnya pada materi dinamika partikel, peneliti memberikan pertanyaan kepada siswa " ketika anda berada dalam mobil yang sedang melaju, tiba-tiba mobil direm secara mendadak ,apa yang terjadi? Kemudian siswa menjawab seperti yang mereka alami. Kemudian peneliti memunculkan permasalahan yang sering terjadi, apakah masih ada peristiwa lain atau contoh peristiwa yang berkaitan dengan dinamika partikel.

Disinilah siswa mengeluarkan berbagai pendapat seperti yang mereka alami, kemudian muncul pendapat yang menimbulkan konflik kognitif. Kemudian peneliti menjelaskan tentang materi Dinamika partikel. Pada tahap ini peneliti menanamkan konsep yang berkaitan dengan materi yang sedang diajarkan. Setelah siswa paham dengan materi tersebut, maka beranjak pada tahap berikutnya yaitu tahap aplikasi.

Pada tahap ini siswa dituntut untuk mampu menerapkan konsep dari materi tersebut dalam melakukan diskusi dengan kelompoknya untuk menjawab LKS yang berisi soal yang berkaitan dengan materi. Siswa bekerja sama dengan kelompoknya membahas soal sehingga semua siswa aktif terlibat dalam diskusi dalam memecahkan masalah. Saling berinteraksi dengan guru untuk menanyakan permasalahan yang terdapat dalam soal, setelah perwakilan salah satu kelompok mempresentasikan hasil diskusi kemudian kelompok lain menanggapi apabila terjadi miskonsepsi sehingga semua kelompok terlibat. Dan guru meluruskan 
p-ISSN 2338-3240, e-ISSN 2580-5924

permasalahan dengan mengevaluasi masalah tersebut bersama-sama siswa agar tidak terjadi miskonsepsi.

Hasil yang diperoleh dari penelitian tersebut dimungkinkan karena dalam pembelajaran menggunakan model group investigation, siswa terlibat berperan aktif dalam proses pembelajaran dan secara kreatif berusaha menemukan permasalahan yang diajukan, saling berinteraksi dengan teman maupun guru, saling bertukar pikiran, sehingga wawasan dan daya pikir mereka berkembang. Hal ini sesuai dengan ungkapan ${ }^{[8]}$, kelompok siswa yang mengikuti model pembelajaran group investigation dengan kelompok siswa yang mengikuti pembelajaran konvensional terhadap hasil belajar fisika. Penelitian tersebut menunjukan hasil belajar fisika yang sangat signifikan.

Model pembelajaran group investigation yang diterapkan menemui kendala saat proses pembelajaran berlangsung. Bagi peneliti beberapa kendala tersebut adalah sulitnya mengalokasikan waktu dengan tepat, karena model pembelajaran group investigation ini memiliki tahapan yang cukup banyak. Hal ini disebabkan dalam menguasai kelas.

Model pembelajaran think pair square digunakan untuk meningkatkan kemampuan berpikir, berkomuikasi dan mendorong siswa untuk berbagi informasi dengan siswa lain. Hal ini disebabkan oleh penerapan think pair square yang memberikan kesempatan kepada siswa mendiskusikan ide-ide mereka dan memberikan suatu pengertian kepada mereka untuk melihat cara lain dalam menyelesaikan masalah.

Pada tahap think guru mengkondisikan siswa untuk siap menerima pelajaran dengan memberikan informasi dan fenomena yang terkait dengan materi yang diajarkan dengan cara memberikan masalah yang sering mereka lakukan, sehingga akan menimbulkan konflik kognitif pada siswa. Misalnya pada materi dinamika partikel, peneliti memberikan pertanyaan kepada siswa" apa yang terjadi ketika anda berenang? Kemudian siswa menjawab seperti yang mereka alami. Kemudian peneliti memunculkan permasalahan yang sering terjadi, apakah masih terdapat peristiwa yang berkaitan dengan dinamika partikel? Disinilah siswa mengeluarkan berbagai pendapat sesuai yang mereka ketahui, kemudian muncul pendapat yang menimbulkan konflik kognitif. Kemudian peneliti menjelaskan materi dinamika partikel dengan tujuan menanamkan konsep yang berkaitan dengan materi yang sedang diajarkan, setelah siswa paham guru memberikan LKS kepada seluruh siswa dan siswa mengerjakan secara individu sehingga siswa dapat berfikir secara mandiri.

Tahap selanjutnya yaitu tahap pair, pada tahap ini siswa berdiskusi dengan pasangan yang sudah ditentukan oleh guru mengenai jawaban LKS yang dikerjakan secara individu atau siswa berdiskusi mengenai jawaban mereka sebelumnya, sehingga mereka menyepakati jawaban yang akan dijadikan bahan diskusi kelompok. Tahap square, pada tahap ini setiap pasangan berbagi hasil pemikiran mereka dengan pasangan lain dalam satu kelompok yaitu dengan cara pasangan bertemu dalam satu kelompokan untuk berdiskusi menjawab permasalahan yang sama. Tahap selanjutnya diskusi kelas, pada tahap ini beberapa kelompok tampil di depan kelas secara bergiliran untuk mempresentasikan hasil jawaban LKS selanjutnya guru mengevaluasi pemahaman siswa melalui evaluasi sub pokok bahasan untuk mengetahui ketercapaian indikator pembelajaran dan siswa dinilai secara individu dan kelompok.

Model pembelajaran think pair square yang diterapkan di kelas eksprimen 2 juga mempunyai kelebihan tentang keaktifan siswa ketika berdiskusi bersama kelompoknya dan adanya waktu berpikir yang memberikan kesempatan kepada siswa untuk berpikir mengenai jawaban mereka sendiri sebelum pertanyaan tersebut dijawab oleh siswa lain. Selain itu guru dapat mengurangi masalah dari adanya siswa yang mengobrol, karena tiap siswa memiliki tugas untuk dikerjakan sendiri. Pembelajaran think pair square memiliki beberapa kendala dalam pelaksanaan yaitu siswa tidak dapat menanggapi presentasi dari kelompok lain sehingga kurang memiliki kesempatan untuk mengasah kemampuan dalam menyelesaikan masalah dan guru lebih aktif ketika mengevaluasi pemahaman siswa. Pengalokasian waktu dalam setiap tahapnya itu sulit. Jadi inilah yang merupakan faktor penyebab dari lebih kecilnya nilai rata-rata tes akhir pada kelas eksperimen 2 .

\section{KESIMPULAN DAN SARAN}

\section{KESIMPULAN}

1. Berdasarkan analisa data penelitan, maka dapat disimpulkan bahwa terdapat perbedaan hasil belajar fisika antara model pembelajaran Kooperatif tipe group investigation dan model pemebelajaran kooperatif tipe think pair square pada siswa kelas $X$ SMA Negeri 9 Palu. Hal ini ditunjukkan pada uji statistik yaitu uji $t$ diperoleh. Berdasarkan daftar tabel distribusi 
$\mathrm{t}$ diperoleh tabel $=-2,02<$ thitung $=2,11<$ tabel $=2,02$. Hasil uji hipotesis ini memperlihatkan bahwa harga thitung tidak berada di dalam daerah penerimaan Ho atau dengan kata lain $\mathrm{H}_{1}$ diterima pada taraf nyata $\mathrm{a}=0,05$.

2. Eksperimen 1 lebih baik dari eksperimen 2 karena proses pembelajaran eksperimen 1, siswa terlibat secara aktif dan kreatif keseluruan dalam proses pembelajaran dari menanggapi presentasi kelompok dan adanya interaksi dengan guru dalam mengavaluasi pemahaman siswa. Sedangkan ekperimen 2 siswa kurang aktif secara keseluruan dalam proses pembelajaran karena siswa tidak dapat menanggapi presentasi dari kelompok lain sehingga kurang memiliki kesempatan untuk mengasah kemampuan dalam memecahkan masalah dan guru lebih aktif ketika mengevaluasi pemahaman siswa.

\section{SARAN}

Berdasarkan hasil analisis dan pembahasan, diajukan saran-saran:

1. Model pembelajaran ini dapat dijadikan salah satu alternatif model pembelajaran yang menekankan pada pengembangan sains dan teknologi dalam kehidupan masyarakat.

2. Pada penelitian ini pembelajaran dengan menggunakan model pembelajaran kooperatif tipe group investigation hanya terbatas pada materi dinamika partikel, alangkah baiknya jika ada penelitian lanjutan dengan menggunakan model yang sama pada pokok bahasan lainnya, untuk mendapatkan masukan yang lebih lengkap agar pengaruh model ini jelas teramati.

3. Model pembelajaran kooperatif tipe group investigation dapat diterapkan sebagai salah satu alternatif dalam pembelajaran fisika.

\section{DAFTAR PUSTAKA}

[1] Wahyuningsih Indra, dkk. (2012). Penerapan Mode Kooperatif Group Investigation Berbasis Eksperimen Inkuiri Terbimbing untuk Meningkatkan Aktivitas Belajar. Dalam Unnes Physics Education Journal [UPE] (1) (2012)]. Tersedia: http://journal.unnes.ac.id/sju/index.php/upej. november 2014].

[2] Fahrurozy, M. (2013). " Pengaruh Model Pembelajaran Kooperatif Tipe Group Investigation Berbantuan Laboratorium Terhadap Hasil Belajar Fisika Pada Siswa SMA Negei 3 Palu. Skripsi pada Universitas Tadulako Palu: diterbitkan
p-ISSN 2338-3240, e-ISSN 2580-5924

[3] Sudjana,Mudrika (2007) Model Pembelajaran Group Investigation..[online] 8 halaman tersedia : http:// wawan listyawan_blog. blogspot .com /2012/08 makalah Model Pembelajaran html [ 5 november ].

[4] Jumarni. (2013)." Pengaruh Model Pembelajaran Kooperatif Tipe Think Pair Square Terhadap pemahaman Konsep Pada Pokok Bahasan Usaha dan Energi Siswa Kelas VII SMP Negeri 9 Palu : Skripsi pada Universitas Tadulako Palu: diterbitkan

[5] Spancar, Kangan. (1933) Model pembelajaran Think Pair Square. [online] 10 halaman tersedia :http: cerah_bahasa .blogspot .com /2012/03 Makalah Model- Model Pembelajaran html [ 5 november 2014].

[6] Sudjana. (2005). Metode Statistika. Bandung: CV. Tarsito.

[7] Sugiyono. (2009). Metode Penelitian Kuantitatif, Kualitatif dan $R \& D$. Bandung: Alfabeta.

[8] Fauzi, Ahmad, (2012). Pengaruh Model Pembelajaran Kooperatif Tipe Group Investigation terhadap hasil Belajar Siswa pada Materi Pokok Listrik Dinamis di Kelas IX Semester 1 SMP Swasta An-Nizam Medan T.P 2012/2013. Dalam Skripsi Universitas Negeri Medan. 